\title{
Estimation of external gamma radiation dose in the area of Bory Stobrawskie forests (PL)
}

\author{
Agnieszka Dołhańczuk-Śródka
}

Received: 14 February 2011 / Accepted: 16 September 2011 /Published online: 5 October 2011

(C) The Author(s) 2011. This article is published with open access at Springerlink.com

\begin{abstract}
The study assessed the radiological risks associated with the presence of natural and artificial radionuclides in the Bory Stobrawskie forests (PL). Using the conversion factors given by UNSCEAR and the measurements results of ${ }^{232} \mathrm{Th}$ series, ${ }^{238} \mathrm{U}$ series, ${ }^{40} \mathrm{~K}$, and ${ }^{137} \mathrm{Cs}$ specific activities in the $10-\mathrm{cm}$ soil layer the values of absorbed dose $(D)$ and the annual effective dose equivalent derived from terrestrial gamma radiation $(E)$ were calculated. The calculated dose was compared with doses directly measured on the area studied.
\end{abstract}

Keywords Radiological hazard · Radionuclides · Radiation dose

\section{Introduction}

Human beings are exposed to background radiation that stems both from natural and man-made sources. In general, approximately $85 \%$ of the annual total radiation dose of any person comes from natural radionuclides of both terrestrial and cosmogenic origin (Belivermis et al. 2010; NCRP 1994; UNSCEAR 2000).

A. Dołhańczuk-Śródka $(\bowtie)$

Biotechnology and Molecular Biology, Opole University, ul. kard. B. Kominka 4,

45-032 Opole, Poland

e-mail: agna@uni.opole.pl
Soil radionuclide activity concentration is one of the main determinants of the natural background radiation. A number of decay products of Th and $\mathrm{U}$ series and ${ }^{40} \mathrm{~K}$ are the main components of external gamma radiation originating from soil. About two thirds of natural radioactivity which exposes public is attributed to progeny of $U$ series and ${ }^{222} \mathrm{Rn}$. The worldwide annual effective dose from natural sources is estimated to be $2.4 \mathrm{mSv}$ (UNSCEAR 2000).

Natural radionuclides of the uranium-radium and the thorium series as well as ${ }^{40} \mathrm{~K}$ are distributed in soil almost homogeneously, regardless of the depth. Their concentration depends on local geological conditions. Each year there are seasonal changes in the gamma radiation dose rate value. Additionally, daily changes and changes caused by precipitation are observed. These changes are due to differences in exhalation of radon from soil and in the case of precipitation-washing out radon isotopes from the air and deposition on the soil surface (Biernacka et al. 2004).

As a result of nuclear explosions carried out in the earth's atmosphere and the Chernobyl nuclear power station accident, the world has become polluted with radionuclides of artificial origin. Some of these longlived isotopes (e.g., ${ }^{137} \mathrm{Cs}$ ) are still eminent in the environment predominantly in surface soil, as a result of radioactive fallout from the atmosphere (Celik et al. 2008).

Radioisotopes that are present in soil significantly affect terrestrial gamma radiation levels. In the last 
decade, several studies were carried out to assess the average outdoor terrestrial gamma dose rate in air (e.g., Taskin et al. 2009; Radenković et al. 2009; Belivermis et al. 2010; Baykara and Doğru 2009; Lee et al. 2009; Faheem et al. 2008; Ngachin et al. 2008; Janković et al. 2008; Degerlier et al. 2008; Psichoudaki and Papaefthymiou 2008; El-Taher et al. 2010; AlHamarneh and Awadallah 2009; Nada et al. 2009).

In this paper the radiological risks associated with the presence of natural and artificial radionuclides in the Bory Stobrawskie was assessed. For this purpose radiation doses of gamma radiation were measured in situ using portable gamma spectrometer InSpector1000 (Canberra). Additionally the surface soil samples of the width $10 \mathrm{~cm}$ were collected and gamma radioactivity concentrations of isotopes were determined in the laboratory. From the data obtained, the doses of gamma radiation were calculated using appropriate formulas. Results of this work are important both in assessment of the risk for human health as well as in development of radiobiomonitoring methods.

\section{Materials and methods}

Soil samples were collected according to established procedures. About $2 \mathrm{~kg}$ of soils samples were collected from the top $10 \mathrm{~cm}$ of the soil. Soil samples were collected in October 2009. They were taken from Bory Stobrawskie forest, located in the northeast direction from Opole (PL) at 21 locations as shown in Fig. 1. To diminish an influence of rainfall and soil moisture on measurements results (UNSCEAR 2000), the investigations were performed during dry weather, at least 2 days after rainfall. The position of the locations was determined by using global positioning system. The samples were dried at $110^{\circ} \mathrm{C}$ for night and day. Each of the samples were then weighed and sealed in Marinelli beakers, $450 \mathrm{~cm}^{3}$. They were stored for 4 weeks to achieve equilibrium for ${ }^{238} \mathrm{U}$ and ${ }^{232} \mathrm{Th}$ with their respective progeny.

The measurement of activity in samples of woodland soil was carried out by means of a gamma spectrometer with a germanium detector HPGe (Canberra) of high resolution: $1.29 \mathrm{keV}$ (FWHM) at $662 \mathrm{keV}$ and $1.70 \mathrm{keV}$ (FWHM) at 1,332 keV. Relative efficiency was $21.7 \%$. Energy and efficiency calibration of the gamma spectrometer was performed with the standard solutions type MBSS 2 (Czech Metrological Institute, Praha), which covers an energy range from 59.54 to $1,836.06 \mathrm{keV}$. Geometry of calibration source was Marinelli $\left(447.7 \pm 4.48 \mathrm{~cm}^{3}\right)$, with density $0.985 \pm 0.01 \mathrm{~g} / \mathrm{cm}^{3}$, containing ${ }^{241} \mathrm{Am}$, ${ }^{109} \mathrm{Cd},{ }^{139} \mathrm{Ce},{ }^{57} \mathrm{Co},{ }^{60} \mathrm{Co},{ }^{137} \mathrm{Cs},{ }^{113} \mathrm{Sn},{ }^{85} \mathrm{Sr},{ }^{88} \mathrm{Y}$, and ${ }^{203} \mathrm{Hg}$. Geometry of samples container was Marinelli, $450 \mathrm{~cm}^{3}$. Measuring process and analysis of spectra were computer controlled with use of the software GENIE 2000. The radiation spectrum was recorded day and night.

The activity concentrations of ${ }^{232} \mathrm{Th}$ and ${ }^{238} \mathrm{U}$ were calculated assuming secular equilibrium was established with their decay products. For concentrations of ${ }^{232} \mathrm{Th}$ and ${ }^{238} \mathrm{U}$, the following gamma transition lines were used: ${ }^{232} \mathrm{Th}$ series, ${ }^{228} \mathrm{Ac}$ $(911 \mathrm{keV}) ;{ }^{238} \mathrm{U}$ series, ${ }^{214} \mathrm{~Pb}(351.9 \mathrm{keV})$ and ${ }^{214} \mathrm{Bi}$ $(609.2 \mathrm{keV})$. The activity concentration of ${ }^{40} \mathrm{~K}$ was determined from the peak area of $1,460 \mathrm{keV}$ line. The $661.66 \mathrm{keV}$ gamma transition was used to determine the ${ }^{137} \mathrm{Cs}$ concentration.

Gamma radiation dose rate $(H)$ was determined with Canberra portable scintillation spectrometer InSpector1000. This spectrometer is an easy to use, hand-held, digital and multichannel analyzer ideal for the environment monitoring purposes. The dose measured corresponds to the equivalent dose on the depth $10 \mathrm{~mm}$ of human tissue $\left(H^{*} 10\right)$. This quantity estimates the effective dose of radiation for all types of penetrating radiation, including cosmic radiation (User's Manual 2004). The spectrum analysis was carried out using Genie-2000 (Gamma Analysis Option model S501C) software package.

\section{Results and discussions}

The results of activity concentrations in the soil samples in the Bory Stobrawskie area are given in Table 1 for the radionuclides, and $\delta$ is measurement uncertainty. In this table $\min$ is the lowest value in data, Q1 is the lower quartile, median is the median, mean is the arithmetic mean, Q3 is the upper quartile, and max is the highest value.

The concentrations found in the present study ranged from 3.35 to $10.68 \mathrm{~Bq} / \mathrm{kg}$ dry mass (d.m.; the mean is $6.94 \mathrm{~Bq} / \mathrm{kg}$ d.m.) for ${ }^{238} \mathrm{U}$ series, from 0.00 to $12.90 \mathrm{~Bq} / \mathrm{kg}$ d.m. (the mean is $7.86 \mathrm{~Bq} / \mathrm{kg} \mathrm{d.m}$.) for 
Fig. 1 Locations of soil samples

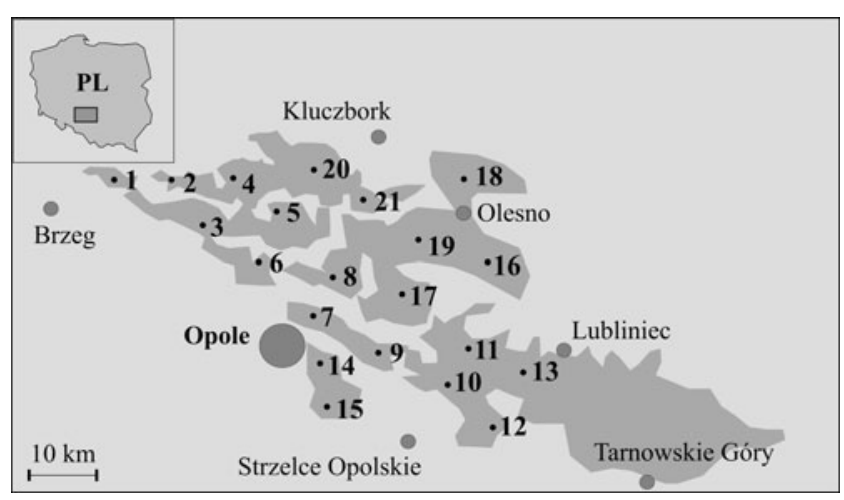

${ }^{232} \mathrm{Th}$ series, from 73.6 to $214.7 \mathrm{~Bq} / \mathrm{kg}$ d.m. (the mean is $147.6 \mathrm{~Bq} / \mathrm{kg}$ d.m.) for ${ }^{40} \mathrm{~K}$, and from 9.2 to $696.3 \mathrm{~Bq} / \mathrm{kg}$ d.m. (the mean is $178.9 \mathrm{~Bq} / \mathrm{kg} \mathrm{d.m.)}$ for ${ }^{137} \mathrm{Cs}$.

The activity concentrations of ${ }^{238} \mathrm{U}$ and ${ }^{232} \mathrm{Th}$ series and ${ }^{40} \mathrm{~K}$ measured in becquerels per kilogram were used to calculate the dose rate, $D$, in nanograys per hour at a height of $1 \mathrm{~m}$ above the ground using the following relationship (UNSCEAR 2000):

$D_{\mathrm{I}}(\mathrm{nGy} / \mathrm{h})=0.604 \mathrm{C}_{\mathrm{Th}}+0.462 \mathrm{C}_{\mathrm{U}}+0.042 \mathrm{C}_{\mathrm{K}}$

Because the area where research was conducted is contaminated by ${ }^{137} \mathrm{Cs}$ in calculations activity of this isotope was considered and the dose was calculated from Eq. 2 (Celik et al. 2008; Jibiri and Bankole 2006; Jibiri et al. 2007):

$D_{\mathrm{II}}(\mathrm{nGy} / \mathrm{h})=0.427 \mathrm{C}_{\mathrm{U}}+0.662 \mathrm{C}_{\mathrm{Th}}+0.043 \mathrm{C}_{\mathrm{K}}+0.03 \mathrm{C}_{\mathrm{Cs}}$

Table 2 shows outdoor absorbed dose rates in air inferred from concentrations of radionuclides in soil. Table 3 shows the average radionuclides activities in soil and absorbed doses in air from different part of the world, compared with those of the present study. Table 3 shows that the measurement average activities natural radionuclides are lower than the world average value.

In the case of isotope ${ }^{137} \mathrm{Cs}$, activity is much higher. This is due to the fact that the area of performance measurement Bory Stobrawskie coincides with the Opole Anomaly, the area where ${ }^{137}$ Cs activity after the nuclear power plant breakdown in Chernobyl has been elevated.

In Figs. 2 and 3 the distributions of doses calculated from Eqs. 1 and 2 are shown. A gray bar located on the $x$-axis shows the range that contains $95 \%$ of the values. In Table 3 the calculated and measured values of radiation suppose that dose rates are lower than those given in the world average value of $51 \mathrm{nGy} /$ h (UNSCEAR 2000).

To estimate the annual effective doses, one has to take into account the conversion coefficient from absorbed dose rate in air to effective dose and

Table 1 Characteristics of the radioactivity of soils in the Bory Stobrawskie area

\begin{tabular}{|c|c|c|c|c|c|c|c|c|}
\hline & \multicolumn{8}{|c|}{ Radioactivity concentration (Bq/kg d.m.) } \\
\hline & ${ }^{238} \mathrm{U}$ series & $\delta{ }^{238} \mathrm{U}$ series & ${ }^{232}$ Th series & $\delta^{232} \mathrm{Th}$ series & ${ }^{40} \mathrm{~K}$ & $\delta^{40} \mathrm{~K}$ & ${ }^{137} \mathrm{Cs}$ & $\delta^{137} \mathrm{Cs}$ \\
\hline Min & 3.35 & 0.34 & 0.00 & 0.00 & 73.6 & 5.9 & 9.2 & 0.3 \\
\hline Q1 & 5.46 & 0.48 & 6.47 & 0.55 & 131.5 & 7.4 & 28.8 & 1.1 \\
\hline Median & 6.73 & 0.65 & 7.85 & 0.68 & 152.9 & 8.5 & 46.8 & 2.5 \\
\hline Mean & 6.94 & 1.47 & 7.86 & 1.33 & 147.6 & 10.4 & 178.9 & 5.8 \\
\hline Q3 & 8.21 & 1.20 & 8.74 & 1.29 & 174.6 & 12.0 & 277.4 & 6.3 \\
\hline Max & 10.68 & 7. 76 & 12.90 & 7.67 & 214.7 & 26.7 & 696.3 & 43.9 \\
\hline
\end{tabular}


Table 2 Outdoor absorbed dose rates in air inferred from concentrations of radionuclides in soil

\begin{tabular}{lcr}
\hline \multicolumn{3}{c}{ Calculated dose rate } \\
\cline { 2 - 3 } & $D_{\mathrm{I}}(\mathrm{nGy} / \mathrm{h})$ & $D_{\mathrm{II}}(\mathrm{nGy} / \mathrm{h})$ \\
\hline Min & 4.642 & 5.90 \\
Q1 & 12.54 & 13.18 \\
Median & 13.81 & 19.44 \\
Mean & 14.15 & 19.88 \\
Q3 & 16.58 & 25.65 \\
Max & 19.67 & 35.01 \\
\hline
\end{tabular}

the outdoor occupancy factor. In the UNSCEAR recent report (UNSCEAR 2000), the committee used $0.7 \mathrm{~Sv} / \mathrm{Gy}$ for the conversion coefficient from absorbed dose in air to effective dose received by adults, and 0.8 for the indoor occupancy factor, implying that $20 \%$ of the time is spent outdoors, on average, around world. The effective dose equivalent rate, in units of millisievert/year, is calculated from the following formula:

$$
\begin{aligned}
E(\mathrm{mSv} / \text { year })= & D(\mathrm{nGy} / \mathrm{h}) \times 24(\mathrm{~h}) \times 365(\text { day }) \\
& \times 0.2(\text { spent outdoors }) \\
& \times 0.7 \text { conversion coefficient } \times 10^{-6}
\end{aligned}
$$

In Table 4 the outdoor absorbed dose rates in air inferred from concentrations of radionuclides in soil compared with the direct measurements are shown. The data in Table 4 show that the results of measurements in situ are almost one order of magnitude higher than the calculated dose values. This is a result of differences between measured and calculated dose rates. The spectrometer Inspector 1000 calculates the $H \times 10$ dose in which more than in $E_{\mathrm{I}}$ and $E_{\mathrm{II}}$ radiation sources are taken into account.

The maximum recorded gamma radiation dose rate was $0.050 \mu \mathrm{Sv} / \mathrm{h}(0.438 \mathrm{mSv} /$ year $)$. This dose is lower than the dose limit referred to in the Regulation

\begin{tabular}{|c|c|c|c|c|c|}
\hline \multirow[t]{2}{*}{ Country } & \multicolumn{3}{|c|}{$\begin{array}{l}\text { Averaged radionuclide activity } \\
\text { in soil }(\mathrm{Bq} / \mathrm{kg} \text {; UNSCEAR 2000) }\end{array}$} & \multirow{2}{*}{$\begin{array}{l}\text { Average activity }{ }^{137} \mathrm{Cs} \text { in soil } \\
(\mathrm{Bq} / \mathrm{kg}) \text {, Anonymous } 1998 \\
{ }^{137} \mathrm{Cs}\end{array}$} & \multirow{2}{*}{$\begin{array}{l}\text { Absorbed dose rate } \\
\text { in air }(\mathrm{nGy} / \mathrm{h}) \text {, UNSCEAR } \\
2000\end{array}$} \\
\hline & ${ }^{238} \mathrm{U}$ series & ${ }^{232} \mathrm{Th}$ series & ${ }^{40} \mathrm{~K}$ & & \\
\hline Belgium & 26 & 27 & 380 & 11.6 & 43 \\
\hline Bulgaria & 45 & 30 & 400 & - & 70 \\
\hline China & 32 & 41 & 440 & - & 62 \\
\hline Denmark & 17 & 19 & 460 & 34.6 & 52 \\
\hline Greece & 25 & 21 & 360 & 48.0 & 56 \\
\hline Hong Kong & 59 & 95 & 530 & - & 87 \\
\hline India & 29 & 64 & 400 & - & 56 \\
\hline Iran & 28 & 22 & 640 & - & 71 \\
\hline Japan & 33 & 28 & 310 & - & 53 \\
\hline Luxemburg & 35 & 50 & 620 & 20.5 & 49 \\
\hline Poland & 26 & 21 & 410 & 25.5 & 45 \\
\hline Portugal & 44 & 51 & 840 & - & 84 \\
\hline Romania & 32 & 38 & 490 & 58.8 & 59 \\
\hline Spain & 32 & 33 & 470 & 5.0 & 76 \\
\hline Switzerland & 40 & 25 & 370 & 58.13 & 45 \\
\hline United States of America & 40 & 35 & 370 & - & 47 \\
\hline World average & $8-160(32)$ & $4-130(40)$ & $100-700(420)$ & - & - \\
\hline Present study & 6.94 & 7.86 & 147.6 & 178.9 & 14 \\
\hline
\end{tabular}

Table 3 Average radionuclides activities in soil and absorbed doses in air from different part of the world, compared with those of the present study 
Fig. 2 Histogram of $D_{\mathrm{I}}$ distribution calculated from Eq. 1

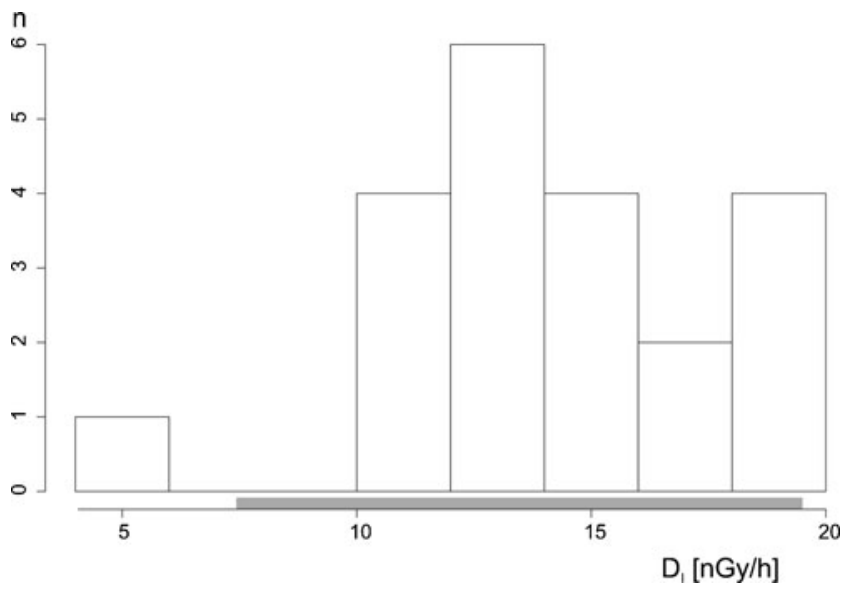

level $<0.001$. For means comparison the $t$ test for samples with different variances was used. It was found that both mean $E_{\mathrm{I}}$ and $E_{\mathrm{II}}$ were significantly different than mean $H$, at $p$ level $<0.001$. Additionally to compare results obtained from two different methods of doses calculation and the measured dose, the $t$ test for pairs was used. Here again significant influence of dose determination method on the result was confirmed, at $p$ level 0.001 .

Rather poor relationship between $E_{\mathrm{I}}$ and $H$ was found. The correlation coefficient value was 0.46 , supposing existence of other important sources of gamma radiation in environment that were not included in the formula used in calculations. Further statistical analysis revealed a relationship between $E_{\mathrm{II}}$ and $H$. In the range of the measured $H$ doses, a good linear relationship with calculated $E_{\mathrm{II}}$ can be concluded (Fig. 4). The slope of the relationship was 8.3 (with standard error 1.2), the intercept was 0.00 (with
Fig. 3 Histogram of $D_{\mathrm{II}}$ distribution calculated from Eq. 2

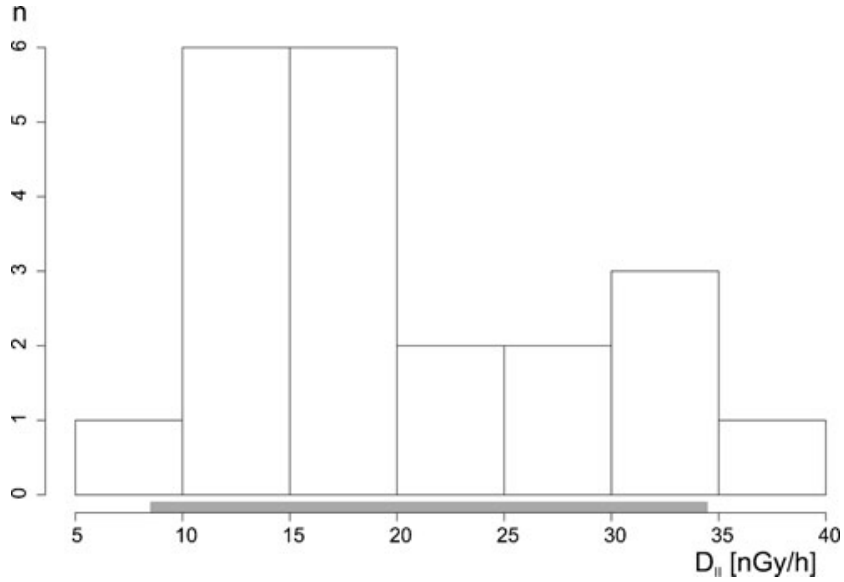


Table 4 Outdoor absorbed dose rates in air inferred from concentrations of radionuclides in soil compared with direct measurements

\begin{tabular}{llcl}
\hline & \multicolumn{2}{l}{ Calculated dose rate } & \multicolumn{2}{l}{ Measured dose rate } \\
\cline { 2 - 3 } & $E_{\mathrm{I}}(\mathrm{mSv} /$ year $)$ & $E_{\mathrm{II}}(\mathrm{mSv} /$ year $)$ & $H(\mathrm{mSv} /$ year $)$ \\
\hline Min & 0.0057 & 0.0072 & 0.105 \\
Q1 & 0.0154 & 0.0162 & 0.131 \\
Median & 0.0169 & 0.0226 & 0.175 \\
Mean & 0.0174 & 0.0244 & 0.204 \\
Q3 & 0.0203 & 0.0315 & 0.254 \\
Max & 0.0241 & 0.0429 & 0.438 \\
\hline
\end{tabular}

standard error 0.03 ), and the value of correlation coefficient was 0.86 . The intercept value did not differ significantly from 0 , and the relationship can be simplified to proportion. It can by concluded that the values of the measured dose rate $H$ is about eight times bigger than the calculated $E_{\mathrm{II}}$ and contribution of ${ }^{137} \mathrm{Cs}$ has to be taken into consideration while estimation of gamma radiation dose rate.

Direct measurement on the level of $1 \mathrm{~m}$ above the ground detects radiation from a large area. Additionally, in situ measurement detects activity of isotopes occurring in other than soil parts of the environment and cosmic rays. Therefore, direct measurement of gamma dose rate seem to be more representative for area studied than the dose rate calculated from the known activity of isotopes in the soil. Comparing the ranges of activity changes of ${ }^{232} \mathrm{Th}$ series, ${ }^{238} \mathrm{U}$ series, ${ }^{40} \mathrm{~K}$, and ${ }^{137} \mathrm{Cs}$, one can notice that changes in radiocesium activities in soil were the highest. Relatively uniformly distributed activities of natural soil isotopes composed mainly the average dose, whereas ${ }^{137} \mathrm{Cs}$ activities caused variability in radiation doses.
It can be supposed that on the area investigated, other than soil radiation sources determinate radiation dose rate. Specific influence of ${ }^{137} \mathrm{Cs}$ on radiation dose can be supposed. Because of similarity of its chemical properties to $\mathrm{K}$, it can be efficiently transported from soil to forest plants, raising the total dose of radiation from the sources other than soil.

Though a considerable difference between gamma dose rate was determined in situ and measured, it is possible to recalculate the doses obtained using different methods. It is particularly important in situations when only soil samples are available for measurements.

\section{Conclusions}

- The radioactivities of natural isotopes determined in the 10-cm layer of soil on the area studied did not exceed the average world value;

- In calculations of gamma dose rate, the local radioactive contamination has to be taken into account;

- Sources of radiation other than soil determine dose rate on the examined area;

- Calculated and directly measured values of gamma radiation doses are lower than the dose limit set out by the Council of Ministers Ordinance of 18 January 2005 (Regulation of the Council of Ministers (Poland); Anonymous 2005);

- The data obtained are important both for assessing the risk for human health as well as environmental radiobiomonitoring;

- The results can be used as a reference point for radiological mapping the area of Bory Stobrawskie forests.
Fig. 4 Relationship between measured and the calculated gamma dose rates

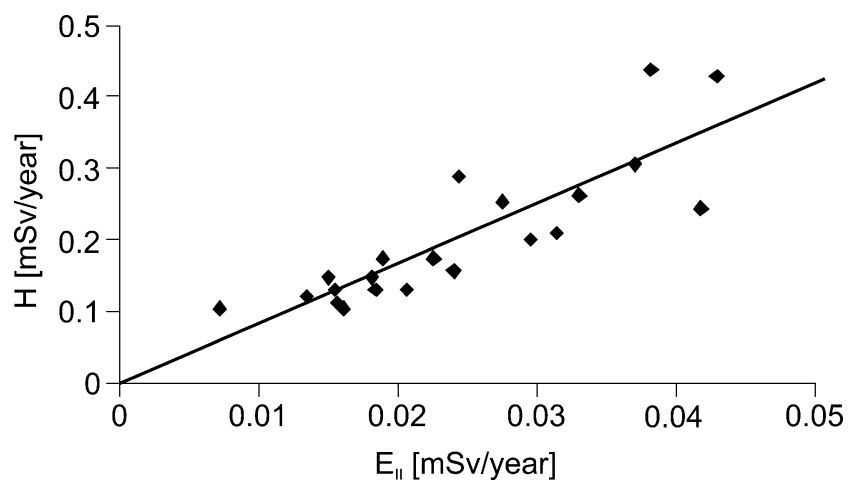


Open Access This article is distributed under the terms of the Creative Commons Attribution Noncommercial License which permits any noncommercial use, distribution, and reproduction in any medium, provided the original author(s) and source are credited.

\section{References}

Al-Hamarneh, I. F., \& Awadallah, M. I. (2009). Soil radioactivity levels and radiation hazard assessment in the highlands of northern Jordan. Radiations Measurements, $44,102-110$.

Anonymous. (1998). Atlas of caesium deposition on Europe after the Chernobyl accident, EU publication, EUR 16733, Luxembourg, http://ipta.demokritos.gr/erl/csatlas.html. Accessed 10 January 2011.

Anonymous. (2005). Regulation of the Council of Ministers (Poland) on ionizing radiation dose limits. http://www.paa. gov.pl/en/doc/atomic_law/2005-168.pdf. Accessed 10 January 2011 .

Baykara, O., \& Doğru, M. (2009). Determination of terrestrial gamma, ${ }^{238} \mathrm{U},{ }^{232} \mathrm{Th}$ and ${ }^{40} \mathrm{~K}$ in soil along fracture zones. Radiations Measurements, 44, 116-121.

Belivermis, M., Kılıç, Ö., Çotuk, Y., \& Topcuoğlu, S. (2010). The effects of physicochemical properties on gamma emitting natural radionuclide levels in the soil profile of Istanbul. Environmental Monitoring and Assessment, 163, 15-26.

Biernacka, M., Lipiński, P., \& Sosińska, A. (2004). Ocena skażeń promieniotwórczych gleby oraz tła promieniowania gamma $w$ Polsce $w$ latach 1988-2001. Warszawa: Biblioteka Monitoringu Środowiska. in Polish.

Celik, N., Cevik, U., Celik, A., \& Kucukomeroglu, B. (2008). Determination of indoor radon and soil radioactivity levels in Giresun, Turkey. The Journal of Environmental Radioactivity, 99, 1349-1354.

Degerlier, M., Karahan, G., \& Ozger, G. (2008). Radioactivity concentrations and dose assessment for soil samples around Adana, Turkey. The Journal of Environmental Radioactivity, 99, 1018-1025.

El-Taher, A., Makhluf, S., Nossair, A., \& Abdel Halim, A. S. (2010). Assessment of natural radioactivity levels and radiation hazards due to cement industry. Applied Radiation and Isotopes, 68, 169-174.

Faheem, M., Mujahid, S. A., \& Matiullah. (2008). Assessment of radiological hazards due to the natural radioactivity in soil and building material samples collected from six districts of the Punjab province-Pakistan. Radiations Measurements, 43, 1443-1447.

InSpector1000 Digital Hand-Held MCA, User's Manual 9236111CV1.1 (2004).

Janković, M., Todorović, D., \& Savanović, M. (2008). Radioactivity measurements in soil samples collected in the Republic of Srpska. Radiations Measurements, 43, 1448-1452.

Jibiri, N. N., \& Bankole, S. O. (2006). Soil radioactivity and radiation absorbed dose rates at roadsides in high-traffic density areas in Ibadan Metropolis, southwestern Nigeria. Radiation Protection Dosimetry, 118, 453-458.

Jibiri, N. N., Farai, P. I., \& Alausa, K. S. (2007). Estimation of annual effective dose due to natural radioactive elements in ingestion of foodstuffs in tin mining area of Jos-Plateau, Nigeria. The Journal of Environmental Radioactivity, 94, $31-40$.

Lee, S. K., Wagiran, H., Ramli, A. T., Apriantoro, N. H., \& Wood, A. K. (2009). Radiological monitoring: terrestrial natural radionuclides in Kinta District, Perak, Malaysia. The Journal of Environmental Radioactivity, 100, 368374.

Nada, A., Abd-El Maksoud, T. M., Abu-Zeid Hosnia, M., ElNagar, T., \& Awad, S. (2009). Distribution of radionuclides in soil samples from a petrified wood forest in ElQattamia, Cairo, Egypt. Applied Radiation and Isotopes, 67, 643-649.

NCRP. (1994). Exposure of the population inthe United States and Canada from Natural Background Radiation. NCRP Report No: 94. Bethesda, Maryland: NCRPM.

Ngachin, M., Garavaglia, M., Giovani, C., Kwato Njock, M. G., \& Nourreddine, A. (2008). Radioactivity level and soil radon measurement of a volcanic area in Cameroon. The Journal of Environmental Radioactivity, 99, 1056-1060.

Psichoudaki, M., \& Papaefthymiou, H. (2008). Natural radioactivity measurements in the city of Ptolemais (Northern Greece). The Journal of Environmental Radioactivity, 99, 1011-1017.

Radenković, M., Alshikh, S. M., Andrić, V. B., \& Miljanić, Š. S. (2009). Radioactivity of sand from several renowned public beaches and assessment of the corresponding environmental risks. Journal of the Serbian Chemical Society, 74(4), 461-470.

Taskin, H., Karavus, M., Ayb, P., Topuzoglu, A., Hidiroglu, S., \& Karahan, G. (2009). Radionuclide concentrations in soil and lifetime cancer risk due to gamma radioactivity in Kirklareli, Turkey. The Journal of Environmental Radioactivity, 100, 49-53.

UNSCEAR. (2000). Report to the general assembly. Annex B: exposures from natural radiation sources 